\title{
FAKTOR YANG MEMPENGARUHI IMPLEMENTASI PROGRAM DETEKSI DINI KANKER SERVIKS MELALUI PEMERIKSAAN IVA (INSPEKSI VISUAL ASAM ASETAT) DI PUSKESMAS WILAYAH KOTA SURABAYA
}

\author{
Fritria Dwi Anggraini \\ (UNUSA, FKK, Prodi D III Kebidanan - Jl. Smea 57 Surabaya) \\ Email : fritria@unusa.ac.id
}

\begin{abstract}
Cervical cancer detection program through an examination of the IVA has been implemented in all health centers in Surabaya since 2010. Target of this program are $80 \%$ WUS and the target examination at least 25 people per month, but the achievement only 3-4 people permonth. The purpose of research is to analyze the factors that affect the implementation of IVA's programs in healthcare centers in Surabaya. Research conducted observational analytic cross sectional approach. The study population was responsible for IVA program at the health center for 52 people with a total sampling. The data was collected through interviews with questionnaire. Analyzed using T test track with the program VPLS.

The results showed IVA program by parent centers in the city of Surabaya $57.7 \%$ poor, $51.9 \%$ of communication is not good, the attitude of the respondents $55.8 \%$ positive / supportive IVA program, character health centers provide less at $53.8 \%$ support, understanding of the standard and target $51.9 \%$ less understand. Based on the test results showed that the communication model of the structure, characteristics and health centers responsible attitude directly affects the implementation of the program, while managing and understanding of the standard target indirectly influence the IVA program implementation through communication and attitud. Taken together these five factors influence the implementation of the IVA program with a contribution of $82.7 \%$ which is the most influential variable is communication.
\end{abstract}

Keywords : Early detection of cervical cancer, program implementation

\begin{abstract}
ABSTRAK
Program deteksi kanker serviks melalui pemeriksaan IVA diberlakukan di seluruh puskesmas induk di Surabaya sejak 2010. Target sasaran 80\% WUS dan minimal tiap puskesmas di Surabaya 25 orang perbulan, tetapi pencapaian puskesmas hanya 3-4 orang perbulan. Tujuan penelitian menganalisis faktor yang mempengaruhi implementasi program IVA di puskesmas wilayah Kota Surabaya. Penelitian analitik dengan pendekatan cross sectional. Subyek penelitian adalah penanggungjawab program IVA di seluruh Puskesmas induk yang melaksanakan program IVA sebanyak 52 orang. Pengumpulan data melalui wawancara terstruktur. Analisis data dengan analisis jalur uji T pada program VPLS (Visual Partial Least Square)

Hasil penelitian menunjukkan pelaksanaan program IVA oleh puskesmas induk di wilayah Kota Surabaya $57,7 \%$ kurang baik dalam pemetaan sasaran, penyuluhan dan cakupan pemeriksaan. Komunikasi sebesar 51,9\% kurang khususnya tentang kejelasan. Sikap responden 55,8\% positif/mendukung program IVA. Karakter dukungan puskesmas sebesar 53,8\% kurang mendukung dalam implementasi program IVA, pemahaman tentang standar dan sasaran $51,9 \%$ kurang memahami status dan SPM dari program IVA. Hasil uji struktur model didapatkan bahwa komunikasi, karakteristik dukungan puskesmas dan sikap penanggungjawab berpengaruh secara langsung, sedangkan sumberdaya dan pemahaman tentang standar sasaran berpengaruh secara tidak langsung terhadap implementasi program IVA, melainkan melalui komunikasi dan sikap. Secara bersama-sama kelima faktor berpengaruh terhadap implementasi program IVA dengan kontribusi sebesar $82,7 \%$ dimana variabel yang paling berpengaruh adalah komunikasi.
\end{abstract}

Kata Kunci : Deteksi dini kanker servik, Implementasi program 


\section{PENDAHULUAN}

Kanker serviks atau kanker leher rahim adalah penyakit keganasan dari leher rahim (serviks) yang disebabkan oleh virus HPV (Human Papiloma Virus). Diseluruh dunia, penyakit ini merupakan jenis kanker ke dua terbanyak yang diderita perempuan setelah kanker payudara namun menjadi penyebab pertama kematian perempuan akibat kanker. ${ }^{\text {i }}$ Angka kejadian mencapai hampir 20 juta penderita per tahun dan $90 \%$ diantaranya terjadi di negara berkembangseperti Asia selatan, Asia tenggara, Amerika bagian tengah dan selatan serta Afrika timur. ${ }^{2}$

Di Indonesia Angka kejadian kanker serviks terus meningkat setiap tahunnya dengan peningkatan \pm 15.000 kasus, dan 7493 diantaranya berakhir dengan kematian sebab hampir $70 \%$ kasus baru ditemukan sudah dalam keadaan stadium lanjut. Tingginya kejadian kanker serviks di Indonesia tersebut merupakan angka kejadian kanker serviks tertinggi di dunia. $^{3}$

Kasus terbanyak di Indonesia ditemukan di Jawa Timur. Dari laporan POSA (Poli Onkologi Satu Atap) RSUD Dr.Soetomo didapatkan kasus mencapai 2.879 kasus pada tahun 2011 dan 3780 pada tahun 2012, setiap hari ditemukan 810 kasus baru dan dalam 3 tahun terakhir (2010-2012) terjadi peningkatan jumlah pasien baru kanker serviks berturut-turut 1263, 1758 dan 1691 dengan jumlah kematian 40 kasus.

Kanker serviks dapat dicegah dan diobati jika ditemukan/dideteksi pada stadium dini. WHO merekomendasikan seluruh wanita yang aktif berhubungan seks untuk melakukan deteksi dini karena kunci keberhasilan program pengendalian kanker adalah pada penapisan yang efektif dan penanganaan sedini mungkin. Metode skrining deteksi dini kanker serviks dapat dilakukan melalui Tes Pap smear dan inspeksi visual dengan asam asetat (IVA).
Dinas Kesehatan Provinsi Jawa Timur mulai menggerakkan pemeriksaan pemeriksaan kanker serviks oleh puskesmas sejak tahun 2007, namun belum dilaksanakan secara optimal, kemudian tahun 2010 Dinkes Propinsi Jawa Timurdan Dinkes Kota (DKK) Surabaya berkoordinasi dengan sektor terkait serta jejaring kanker untuk melakukan program deteksi dini kanker serviks sesuai dengan Kepmenkes No 796/menkes/VII/2010 dan ditetapkan kepada seluruh puskesmas induk. Program ini mulai dilakukan di kota Surabaya, Malang, Gresik dan Kediri, kemudian akan dikembangkan ke semua kabupaten/kota di Jawa Timur. Kegiatan meliputi penyuluhan kepada masyarakat dan deteksi dini kanker serviks dengan metode IVA.

Berdasarkan survey pendahuluan yang diperoleh penulis melalui wawancara dengan Sie Pelayanan Kesehatan Dasar KIA DKK Surabaya selaku pemegang program IVA dan 4 orang penanggungjawab program IVA dipuskesmas, didapatkan pada tahun 2010-2011dari 62 Puskesmas induk, program ini hanya dilaksanakan oleh 23 (37\%) puskesmas dengan cakupan pemeriksaan sebesar 20,4\%dari sasaran yang sudah dilakukan penyuluhan, bukan dari seluruh sasaran. Pada tahun 2012 DKK Surabaya menetapkan Standar Pelayanan Minimal (SPM) pemeriksaan IVA untuk seluruh puskesmas induk wilayah Surabaya yaitu cakupan pemeriksaan minimal 25 pasien/bulan untuk setiap Puskesmas. Pada tahun 20112012 yang melaksanakan program ini meningkat menjadi 56 puskesmas namun hanya 3 puskesmas yang mencapai target SPM sedangkan 53 puskesmas diantaranya cakupan berada dibawah target minimal yang ditetapkan dengan rata-rata cakupan 7-8 orang/bulan/puskesmas, dan 6 puskesmas lainnya cakupan $0 \%$ dan belum dilakukan penelusuran maupun tindak lanjut dari capaian tersebut. 
Berdasarkan latar belakang yang telah penulis uraikan di atas maka dapat dirumuskan permasalahan kurang optimalnya pelaksanaan program deteksi dini kanker serviks di puskesmas, hal tersebut terlihat dari kurangnya kegiatan penyuluhan kemasyarakat serta rendahnya cakupan pemeriksaan IVA di puskesmas yang masih jauh berada dibawah target baik target SPM.

Dapat di katakan pelaksanaan program deteksi dini kanker serviks melalui pemeriksaan IVA di puskesmas belum optimal namun belum dilakukan penelusuran maupun tindak lanjut dari capaian tersebut, untuk itu penting dilakukan analisa terhadap faktor faktor berpengaruhi terhadap implementasi program deteksi dini kanker serviks di puskesmas wilayah kerja Dinas Kesehatan Kota Surabaya.

\section{METODE PENELITIAN}

Penelitian dilakukan secara observasional analitik dengan pendekatan cross sectional. Unit analisis penelitian puskesmas induk yang sudah melaksanakan program IVA, populasi penanggungjawab program IVA di Puskesmas sebesar 52 orang dengan cara total sampling. Variabel bebas (independent) terdiri dari komunikasi, ketersediaan sumber daya, karakteristik dukungan puskesmas, sikap/disposisi pelaksana, pemahaman tentang standar dan sasaran kebijakan. Variabel terikat (dependent) yaitu implementasi program deteksi dini kanker serviks melalui pemeriksaan IVA. Pengumpulan data dilakukan melalui wawancara dan observasi menggunakan kuesioner terstruktur. Uji dilakukan dengan menggunakan program SEM (Structural Equation Modeling) dengan alternatif model struktur menggunakan VPLS (Visual Partial Least Square) karena jumlah sampel relatif kecil $(\mathrm{n}<100)$, dengan menggunakan taraf signifikansi $5 \% \quad(\mathrm{p}<0.05)$ melalui analisis model struktur (Inner Model) dan model pengukuran (Outer Model).

\section{HASIL PENELITIAN}

\section{Implementasi Program IVA di Puskesmas}

Implementasi program deteksi dini kanker serviks yang dilakukan oleh puskesmas meliputi persiapan, pelaksanaan dan pencatatan pelaporan.

Tabel 1. Implementasi program IVA program IVA di Puskesmas wilayah Surabaya, tahun 2013

\begin{tabular}{lcc}
\hline Implementasi & Frekuensi & Persentase \\
\hline Baik & 22 & 42,3 \\
Kurang & 30 & 57,7 \\
\hline \multicolumn{1}{c}{ Jumlah } & 52 & 100,0 \\
\hline
\end{tabular}

Tabel 2 menunjukkan bahwa implementasi puskesmas dalam program deteksi dini kanker serviks sebagian besar $57,7 \%$ kurang baik.

\section{Komunikasi Dalam Implementasi Program IVA}

Komunikasi dalam penelitian ini merupakan penyampaian informasi/sosialisasi tentang IVA baik antara DKK Surabaya kepada Kepala Puskesmas dan pelaksana program di puskesmas meliputi sosialisasi (sumber, jadwal, metode), kejelasan dan konsistensi.

Tabel 2 Komunikasi program IVA di Puskesmas wilayah Surabaya, tahun 2013

\begin{tabular}{|c|c|c|}
\hline Komunikasi & Frekuensi & Persentase $(\%)$ \\
\hline Baik & 27 & 48,1 \\
\hline Kurang & 25 & 51,9 \\
\hline Jumlah & 52 & 100,0 \\
\hline
\end{tabular}

bahwa komunikasi program deteksi dini kanker serviks di puskesmas $51,9 \%$ belum dilaksanakan dengan baik. 


\section{Disposisi/sikap implementor tentang Program IVA}

Disposisi /sikap dalam hal ini adalah tanggapan pelaksana program deteksi dini kanker serviks terhadap tugas serta respon/dukungan dalam pelaksanaan program deteksi dini kanker serviks, meliputi kemauan dan tanggungjawan serta kecenderungan menerima/mendukung dilaksanakannya program IVA atau sebaliknya.

Tabel 3 Sikap responden tentang program IVA di Puskesmas wilayah Surabaya, tahun 2013

\begin{tabular}{ccc}
\hline Sikap & Frekuensi & Persentase \\
\hline Positif/mendukung & 29 & 55,8 \\
Negatif/ tidak & 23 & 44,2 \\
\hline Jumlah & 52 & 100,0 \\
\hline
\end{tabular}

Tabel 3 menunjukkan bahwa penanggung jawab program/ implementor sebagian besar $(55,8 \%)$ bersikap positif (mendukung) program deteksi dini kanker serviks.

\section{Karakteristik Dukungan Puskesmas terhadap Program IVA}

Karakteristik dukungan mencakup seberapa besar daya dukung dari suatu organisasi terhadap implementasi program, diantaranya meliputi struktur birokrasi, aturan-aturan berupa standar operasional prosedur (SOP) dan pola struktur organisasi meliputi susunan penanggung jawab dan para pelaksana program IVA beserta rincian tugas.

Tabel 4 Karakteristik dukungan puskesmas dalam program IVA di Puskesmas wilayah Surabaya, 2013

\begin{tabular}{ccc}
\hline Sikap & Frekuensi & Persentase \\
\hline Positif/mendukung & 24 & 46,2 \\
Negatif/ tidak & 28 & 53,8 \\
\hline Jumlah & 52 & 100,0 \\
\hline
\end{tabular}

Implementasi program ini relatif kurang mendapatkan dukungan, terbukti dari di $57,7 \%$ puskesmas tidak ada agenda khusus untuk monitoring pelaksanaan dan meningkatkan upaya meningkatkan cakupan, dan $82,7 \%$ menyatakan tidak ada supervisi langsung dari DKK dan pengawasan hanya berdasarkan laporan saja.

\section{Pemahaman implementor tentang Standar dan sasaran kebijakan Program IVA}

Standar dan sasaran kebijakan dalam penelitian ini adalah pemahaman dan kecenderungan implementor tentang standar dan sasaran kebijakan yang hendak dicapai oleh program IVA.

Tabel 5 Pemahaman responden tentang standar dan sasaran program IVA di Puskesmas Surabaya, tahun 2013

\begin{tabular}{lcc}
\hline Pemahaman & Frekuensi & Persentase \\
\hline Baik & 23 & 44,2 \\
Kurang & 29 & 55,8 \\
\hline \multicolumn{1}{c}{ Jumlah } & 52 & 100,0 \\
\hline
\end{tabular}

Tabel diatas menunjukkan bahwa tentang standar dan sasaran program deteksi dini kanker serviks 55,8\% kurang dipahami dengan baik.

Sumber daya (tenaga/SDM, dana, sarana dan prasarana) dalam Program IVA

Sumber daya adalah segala sesuatu yang digunakan untuk memperlancar implementasi program deteksi dini kanker serviks agar berjalan efektif, meliputi sumber daya finansial (dana) dan sumber daya non finansial yaitu, tenaga (SDM), sarana dan prasarana.

Tabel 6 Kategori ketersediaan sumberdaya pada program IVA di Puskesmas wilayah Surabaya, tahun 2013

\begin{tabular}{lcc}
\hline Sumberdaya & Frekuensi & Persentase \\
\hline Baik & 27 & 51,9 \\
Kurang & 25 & 48,1 \\
\hline \multicolumn{1}{c}{ Jumlah } & 52 & 100,0 \\
\hline
\end{tabular}


Sumberdaya dalam pelaksanaan program IVA di Puskesmas Kota Surabaya sebagian besar $(51,9 \%)$ telah sesuai dengan standar pelayanan IVA yang ada pada panduan pelaksanaan program IVA.

\section{Pengaruh Komunikasi, Sikap, Karakteristik Badan Pelaksana, Sumber Daya Serta Standar Dan Sasaran Terhadap Implementasi Program IVA di Puskesmas}

Pengujian model dilakukan dengan 2 tahap, berdasarkan hasil tersebut didapatkan dari uji tahap I terdapat beberapa indikator yang tidak valid dari masing-masing variabel, kemudian indikator yang tidak valid tidak dikutkan dalam pengujian model tahap II dan didapatkan hasil sebagai berikut :

Gambar 1. Model pengaruh antar variabel (inner model) dan uji signifikasi dengan uji $\mathrm{T}$

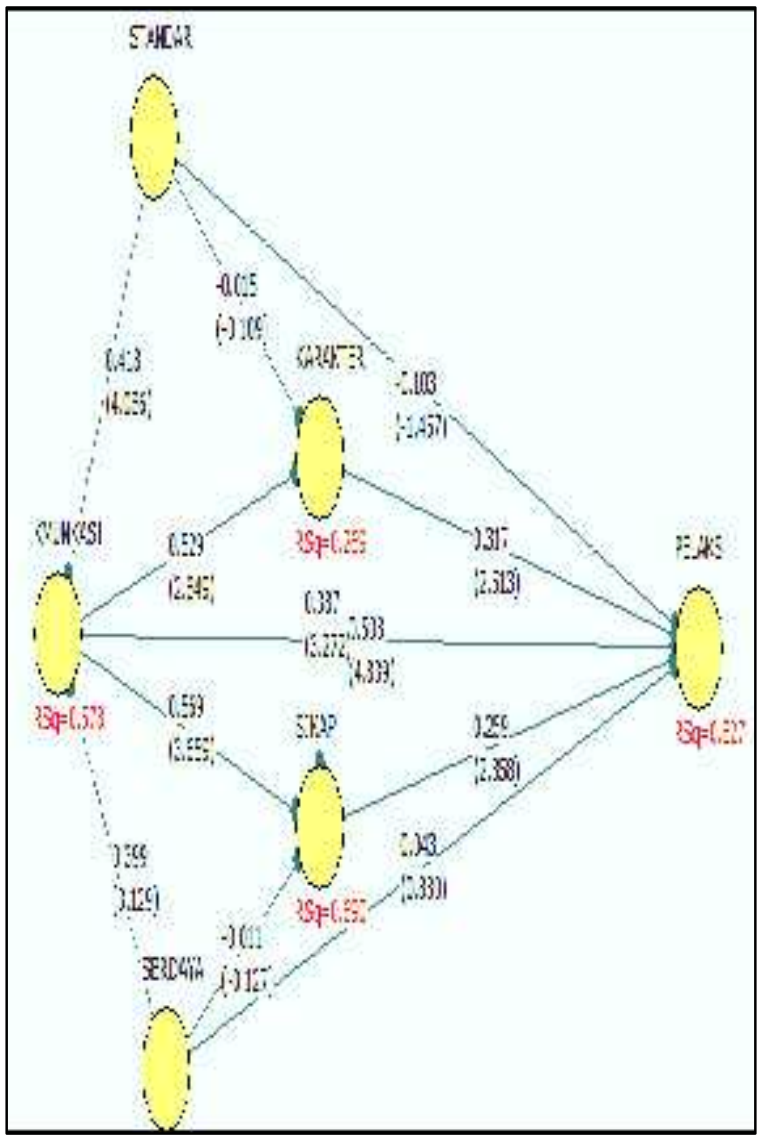

Berdasarkan struktur model dapat dilakukan analisa pengaruh masingmasing variabel terhadap implementasi sebagai berikut :

Tabel 7 Analisa pengaruh variabel bebas terhadap implementasi berdasarkan hasil uji $\mathrm{t}$ pada model

\begin{tabular}{|c|c|c|}
\hline Variabel bebas & $\begin{array}{l}\text { Nilai t } \\
\text { statistic }\end{array}$ & Keterangan \\
\hline Komunikasi & 4,83 & signifikan \\
\hline $\begin{array}{l}\text { Sikap } \\
\text { pelaksana }\end{array}$ & 2,35 & signifikan \\
\hline $\begin{array}{l}\text { Karakteristik } \\
\text { dukungan } \\
\text { puskesmas }\end{array}$ & 2,53 & signifikan \\
\hline Sumberdaya & 0,83 & $\begin{array}{c}\text { tidak } \\
\text { signifikan }\end{array}$ \\
\hline $\begin{array}{l}\text { Pemahaman } \\
\text { standar sasaran }\end{array}$ & 1,45 & $\begin{array}{c}\text { tidak } \\
\text { signifikan }\end{array}$ \\
\hline
\end{tabular}

Gambar 1 menunjukkan bahwa dari 5 variabel yang dihubungkan dengan implementasi didapatkan 3 variabel yang berpengaruh langsung dan signifikan terhadap implementasi yaitu berturut-turut yaitu komunikasi dengan koefisien korelasi 0,529 karakteristik badan pelaksana dengan koefisien korelasi 0,317 dan sikap dengan koefisien korelasi 0,259 ketiganya signifikan karena nilai uji $\mathrm{T}>$ 1,96, sedangkan variabel standar dan sasaran serta variabel sumberdaya tidak berpengaruh secara langsung terhadap implementasi karena nilai $\mathrm{T}<1,96$.

Dalam analisis jalur menggunakan VPLS didapatkan ada varibel bebas (eksogen) dari implementasi dapat menjadi variabel terikat (endogen) bagi variabel lain. Pada model tersebut didasarkan pada kerangka teori van meter didapatkan model dengan 3 variabel endogen (variabel yang dikenai panah) yaitu komunikasi, sikap, karakteristik badan pelaksana dan implementasi dengan nilai $\mathrm{R}^{2}$ masing-masing sebagai berikut : 


\begin{tabular}{lcc}
$\begin{array}{c}\text { Variabel } \\
\text { Eksogen (bebas) }\end{array}$ & $\begin{array}{c}\text { Variabel } \\
\text { Endogen } \\
\text { (terikat) }\end{array}$ & $\begin{array}{c}\text { R-Square } \\
\text { (R2) } \\
\text { model }\end{array}$ \\
\hline $\begin{array}{l}\text { - Karakteristik } \\
\text { dukungan } \\
\text { puskesmas }\end{array}$ & Implementasi & 0,82 \\
- Komunikasi & & \\
- Sikap pelaksana & & \\
- Sumberdaya & & \\
- Pemahaman & & \\
standar dan & & 0,69 \\
sasaran & & \\
\hline - Sumberdaya & $\begin{array}{c}\text { Sikap } \\
\text { - Komunikasi }\end{array}$ & \\
- Karakteristik & & \\
dukungan & & \\
puskesmas & & 0,57 \\
\hline - Sumberdaya & & \\
- Pemahaman & Komunikasi \\
standar sasaran & & 0,26 \\
\hline - Sumberdaya & Karakteristik \\
- Komunikasi & dukungan & \\
& puskesmas & \\
\hline
\end{tabular}

\section{PEMBAHASAN}

\section{Implementasi Program IVA di Puskesmas}

Manajemen pelaksanaan program deteksi dini kanker servik meliputi persiapan(pendataan, estimasi-pemetaan sasaran, estimasi kebutuhan), pelaksanaan (penyuluhan dan cakupan pemeriksaan IVA), serta pencatatan dan pelaporan. ${ }^{5}$

Persiapan merupakan analisis kebutuhan pemeriksaan meliputi analisis kebutuhan dimulai dari pendataan target sasaran, estimasi kebutuhan, serta pemetaan klien sesuai wilayah target sasaran. Berdasarkan hasil wawancara responden dapat dilihat bahwa $82,7 \%$ Puskesmas telah menyusun rencana anggaran berdasarkan perkiraan kebutuhan alat dan sarana, bahkan90,3\% telah menunjuk siapa pelaksana pemeriksaan dan penyuluhan sebelumnya.

Terkait dengan sasaran, $69,1 \%$ puskesmas sudah memperkiraan jumlah sasaran target diwilayah kerjanya yaitu jumlah wanita usia 30-50 tahun yang sudah menikah, namun lemahnya persiapan diantaranya $80,9 \%$ puskesmas tidak melakukan pemetaan target sasaran, begitu pula untuk kerjasama/koordinasi dengan kader/tokoh masyarakat terkait penyuluhan IVA didapatkan $69,2 \%$ tidak melakukanya saat persiapan. Pemetaan dan kerjasama, kedua hal tersebut penting dalam persiapan pelaksanaan program IVA karena besarnya jumlah target disetiap wilayahkarena Surabaya termasuk kota dengan kepadatan penduduk yang cukup tinggi, untuk mempermudah perempuan untuk mencapai akses pelayanan pemeriksaan IVA dengan mengelompokkan sesuai bagian wilayah mulai penyuluhan sampai dengan pemeriksaan. Menurut Azwar persiapan merupakan faktor penunjang yang memeiliki peranan penting dalam membantu pelaksana menyelenggarakan berbagai kegiatan yang telah direncanakan. ${ }^{26}$

Terkait dengan pelaksanaan penyuluhan dan pemeriksaan, sasaran pemeriksaan hampir seluruh puskesmas $(86.5 \%)$ sudah tepat yaitu tidak terbatas hanya pada wanita diwilayah kerjanya saja serta $55.8 \%$ puskesmas juga melakukan rujukan pada kasus yang dicurigai kanker ke fasilitas yang lebih lengkap. Namun jumlah cakupan pemeriksaan IVA di puskesmas sangat jauh dari target yang diharapkan karena hanya 6 puskesmas yang mencapai target SPM, bahkan 26 puskesmas (50\%) sama sekali tidak pernah mencapai target SPM yang ditetapkan DKK. Hal tersebut juga terkait dengan pelaksanaan penyuluhan tentang pemeriksaan IVA, karena dari 52 puskesmas hanya $32.7 \%$ puskesmas yang mengadakan penyuluhan secara rutin dan menyusun jadwal pelaksanaan sedangkan yang lain tidak.Pemeriksaan IVA merupakan hal yang relatif baru bagi masyarakat, untuk itu upaya penyuluhan dan menambah wawasan merupakan hal utama untuk dapat memberdayakan dan menggerakkan masyarakat untuk mau melakukan pemeriksaan, dan hal ini harus dilakukan secara tepat sasaran,terjadwal dan melibatkan kerjasama dengan kader/tokoh masyarakat untuk bisa mencapai seluruh sasaran.

Pencatatan sudah dilaksanakan namun tidak seluruhnya menggunakan format yang sama, bahkan sebagian (36.5\%) puskesmas mengatakan tidak ada format khusus untuk laporan IVA dari puskesmas ke DKK. 
Seluruh puskesmas sudah melaporkan pelaksanaan IVA, namun tidak menyeluruh termasuk kegiatan penyuluhan yang telah dilakukan, melainkan terfokus pada cakupan jumlah pemeriksaan IVA, itupun $55.8 \%$ puskesmas tidak melaporkannya secara rutin setiap bulan, padahal seharusnya pencatatan dan pelaporan secara rutin tiap bulan dengan format yang telah ditetapkan.

Implementasi puskesmas dalam program deteksi dini kanker serviks sebagian besar 57,7 \% kurang baik, khususnya pada aspek persiapan (kerjasama kader dan pemetaan sasaran), serta cakupan kegiatan penyuluhan dan pemeriksaan.

Sasaran target program IVA sangat luas dan bejumlah besar, oleh karena itu persiapan lapangan meliputi pemetaan, advokasi dan sosialisasi, bina suasana, penggerakan masyarakat dan kemitraan lintas program maupun lintas sektor juga sangat diperlukan, untuk itu kader kesehatan berperan dalam motivasi dan pemetaan klien baik untuk mengikuti penyuluhan maupun motivasi dalam melakukan pemeriksaan.

Pemeriksaan IVA sebenarnya merupakan tehnik yang cukup lama ditemukan, namun untuk ditetapkan sebagai program di puskesmas baru berlangsung sejak 2010, terlebih lagi meskipun diharuskan namun program ini bersifat program unggulan sehingga diperkirakan sebagian puskesmas lebih memprioritaskan pelaksanaan pada program pokok yang belum dapat terpenuhi.

\section{Komunikasi Dalam Implementasi Program IVA}

Komunikasi dalam penelitian ini merupakan penyampaian informasi/ sosialisasi tentang IVA baik antara DKK Surabaya kepada Kepala Puskesmas dan pelaksana program di puskesmas meliputi sosialisasi (sumber, jadwal, metode), kejelasan dan konsistensi.

Hasil penelitian menunjukkan bahwa komunikasi program deteksi dini kanker serviks di puskesmas $51,9 \%$ belum dilaksanakan dengan baik, khususnya pada aspek kejelasan juklak dan keharusan program untuk dilaksanakan oleh seluruh puskesmas induk. Koordinator pelaksana program IVA di puskesmas sudah menerima informasi tentang program IVA baik dari Kepala Puskesmas maupun dari DKK, ketetapan pelaksanaan dan target masih belum jelas. Kejelasan informasi sangat bermakna dalam pelaksanaan suatu program kebijakan di puskesmas.

Komunikasi merupakan faktor vital yang memusatkan pada kejelasan standar dan tujuan, akurasi komunikasi para pelaksana dan konsistensi (kesamaan) yang dikomunikasikan dan bermacammacam sumber informasi. program harus dipahami dengan jelas oleh pelaksana, karena pemahaman yang kabur mengenai kebijakan membuat implementasi tidak akan berjalan sesuai yang diharapkan. Van meter dan van horn menyatakan jika komunikasi disampaikan dengan baik maka akan berdampak pada disposisi/ sikap bidan dalam melaksanakan program karena kejelasan standar, tujuan yang konsistensi dan akurasi.

\section{Disposisi/sikap implementor tentang Program IVA}

Sikap menerima atau menolak dari pelaksana akan sangat mempengaruhi keberhasilan kebijakan publik. Disposisi menjaga konsistensi tujuan antara apa yang ditetapkan pengambil kebijakan dan pelaksana kebijakan. implementor 78,8\% responden setuju bahwa IVA merupakan program penting untuk menurunkan kejadian kanker serviks dan 53,8\% setuju bahwa itu adalah tugas dan tanggungjawab puskesmas khususnya responden selaku penanggungjawab program IVA di puskesmas. Terkait hal tersebut agar dapat berjalan optimal $44,2 \%$ responden setuju bahwa pelaksanaan sangat bergantung pada dukungan dan kompensasi dari DKK, bahkan $73 \%$ responden menyatakan bahwa program IVA tidak diwajibkan 
karena selama ini tidak ada sanksi maupun reward bagi puskesmas terkait dengan dilaksanakan atau tidaknya program ini dipuskesmas. Kunc keberhasilan program atau implementasi kebijakan adalah sikap pekerja terhadap penerimaan dan dukungan atas kebijakan atau dukungan yang telah ditetapkan.

\section{Karakteristik Dukungan Puskesmas terhadap Program IVA}

Karakteristik dukungan mencakup seberapa besar daya dukung dari suatu organisasi terhadap implementasi program, diantaranya meliputi struktur birokrasi, aturan-aturan berupa standar operasional prosedur (SOP) dan pola struktur organisasi meliputi susunan penanggung jawab dan para pelaksana program IVA beserta rincian tugas.

Hasil menunjukkan bahwa penanggung jawab program/ implementor sebagian besar $(55,8 \%)$ bersikap positif (mendukung) program deteksi dini kanker serviks menunjukkan bahwa penanggung jawab program/ implementor sebagian besar $(55,8 \%)$ bersikap positif (mendukung) program deteksi dini kanker serviks Terkait dengan struktur organisasi dan karakteristik puskesmas, didapatkan $71,1 \%$ responden menyatakan di puskesmas tidak ada struktur organisasi khusus dalam implementasi program, bahkan $57,7 \%$ penanggungjawab program IVA diantaranya sudah diberikan tanggungjawab lain seperti berperan sebagai bidan koordinator atau dokter penanggungjawab KIA, sehingga tugas dan tanggungjawabnya rangkap/tumpang tindih dan merasa beban kerjanya bertambah. Selain itu 92,3\% tidak mendapatkan reward berupa insentif maupun credit point baik bagi penanggngjawab maupun pelaksana pemeriksaan dan penyuluhann terkait program tersebut baik dari DKK maupun dari operasional puskesmas.

Perlu adanya dukungan puskesmas dalam menciptakan adanya kejasama dari berbagai pihak didalam organisasi puskesmas diantaranya kerja tim, penciptaan lingkungan kerja yang kondusif dan penetapan tentang dilaksanakannya program IVA ini diwilayah kerjanya serta upaya monitoring melalui supervisi baik dari Kepala puskesmas maupun dari DKK. Sesuai dengan pendapat Azrul Azwar bahwa supervisi yang dilakukan oleh seorang atasan penting dilakukan untuk meningkatkan kinerja implementasi terlebih jika supervisi dilakukan melalui pengamatan langsung terhadap pekerjaan yang dilakukan, tidak hanya sebatas pengamatan dokumen saja.

\section{Pemahaman implementor tentang Standar dan sasaran kebijakan Program IVA}

Hasil penelitian menunjukkan bahwa menunjukkan bahwa tentang standar dan sasaran program deteksi dini kanker serviks 55,8\% kurang dipahami dengan baik. Didapatkan $88,5 \%$ responden menganggap/menyetujui bahwa program IVA ini bukan merupakan program pokok melainkan merupakan program unggulan, sehingga tidak harus dilakukan oleh semua puskesmas induk, cukup dilaksanakan oleh rumah sakit atau puskesmas yang sudah PONEK saja. Untuk sasaran 34,8\% diantaranya merasa jumlah sasaran tersebut terlalu banyak dan sulit dicapai oleh puskesmas, bahkan $50 \%$ tidak setuju jika program ini dibebankan pada semua pusekesmas, hal tersebut diperkirakan karena sudah banyaknya program yang ada di puskesmas dan target program pokok puskesmas yang masih belum tercapai.

Penanggungjawab program IVA di Puskesmas mempunyai persepsi yang berbeda-beda dan kurang tepat tentang program IVA khususnya tentang status dan target yang harus diacapai oleh puskesmas terkait dengan tujuan program. pemahaman tentang sasaran kebijakan program IVA. 
Menurut van Meter dan van Horn, standar dan sasaran kebijakan harus jelas dan dipahami dengan tepat oleh penanggungjawab program, untuk itu ketepatan dan kejelasan komunikasi jadi faktor penting dalam karena pemahaman yang tidak tepat dapat mempengaruhi sikap/disposisi implementor dalam melaksanakan suatu program.

Sumber daya (tenaga/SDM, dana, sarana prasarana) dalam Program IVA

Sumberdaya dalam pelaksanaan program IVA di Puskesmas Kota Surabaya sebagian besar telah sesuai dengan standar pelayanan IVA yang ada pada panduan pelaksanaan program IVA, khususnya pada sumberdaya manusia (SDM) dan sarana prasarana yang dibutuhkan. Sarana prasarana yang sifatnya berupa alat dan bahan pendukung kesehatan seperti spekulum, bed ginecology, lidi watten dan sebagainya seluruhnya tersedia cukup dan layak karena alat dan bahan tersebut merupakan standar alat yang memang sudah harus ada di puskesmas terlepas dari adanya program IVA, namun untuk prasarana kegiatan penyuluhan masih sangat minimal, didapatlkan hanya 21,3\% puskesmas yang memiliki banner tentang IVA dan $34,7 \%$ yang menyediakan leaflet saat penyuluhan.

Pencapaian tujuan kebijakan juga harus didukung oleh ketersediaan SDM, dana dan sarana prasarana. Dalam program IVA yeng belum tersedia dengan optimal adalah dana karena tidak adanya dana khusus dari DKK untuk operasinal maing-masing puskesmas. Menurut Winarto ketersediaan sumber daya merupakan faktor penentu kinerja sebuah kebijakan. Implementor harus mendapat sumber-sumber yang dibutuhkan agar program berjalan lancar. Meskipun kebijakan memiliki tujuan dan sasaran yang jelas, namun jika sumber daya tidak memadai atau tidak digunakan secara tepat maka kebijakan tidak akan terlaksana.

\section{Pengaruh Komunikasi, Sikap, Karakteristik Badan Pelaksana, Sumber Daya Serta Standar Dan Sasaran Terhadap Implementasi Program IVA di Puskesmas}

Pada teori Van Meter dan Van Horn, tidak hanya variabel bebas yang dapat mempengaruhi implementasi, melainkan antar variabel bebas juga saling mempengaruhi dan hal tersebut tidak dapat diabaikan. Variabel bebas yang secara langsung tidak berpengaruh pada implementasi program IVA tidak dapat diabaikan karena variabel tersebut dapat mempengaruhi variabel bebas lainnya, dengan kata lain variabel bebas mempengaruhi implementasi baik secara langsung maupun tidak langsung.

Komunikasi, karakteristik dukungan puskesmas dan sikap secara bersamasama berpengaruh langsung terhadap implementasi program IVA, selain itu sumberdaya dan standar sasaran berpengaruh secara tidak langsung terhadap implementasi melalui sikap dan komunikasi. Pada total model implementasi Nilai $R$ square $=0,827$ artinya sumbangan seluruh faktor secara bersama-sama mempengaruhi implementasi sebesar $82,7 \%$, sedangkan $17,3 \%$ lainnya dipengaruhi oleh faktor lain yang tidak diteliti.

Hasil penelitian menunjukkan bahwa dari 5 variabel didapatkan 3 variabel yang berpengaruh langsung dan signifikan terhadap implementasi dengan besar pengaruh berturut-turut Komunikasi, karakteristik dukungan puskesmas dan sikap. Komunikasi 57,8\% dipengaruhi oleh sumberdaya dan pemahaman standar dan sasaran kebijakan, karakteristik dukungan puskesmas 26,9\% dipengaruhi oleh komunikasi serta standar dan sasaran, sedangkan sikap 69\% secara bersamasama dipengaruhi sumberdaya, komunikasi dan karakteritik dukungan pelaksana. 
Berikut ini kerangka teori implementasi yang dikemukakan oleh Van Meter dan Van Horn :

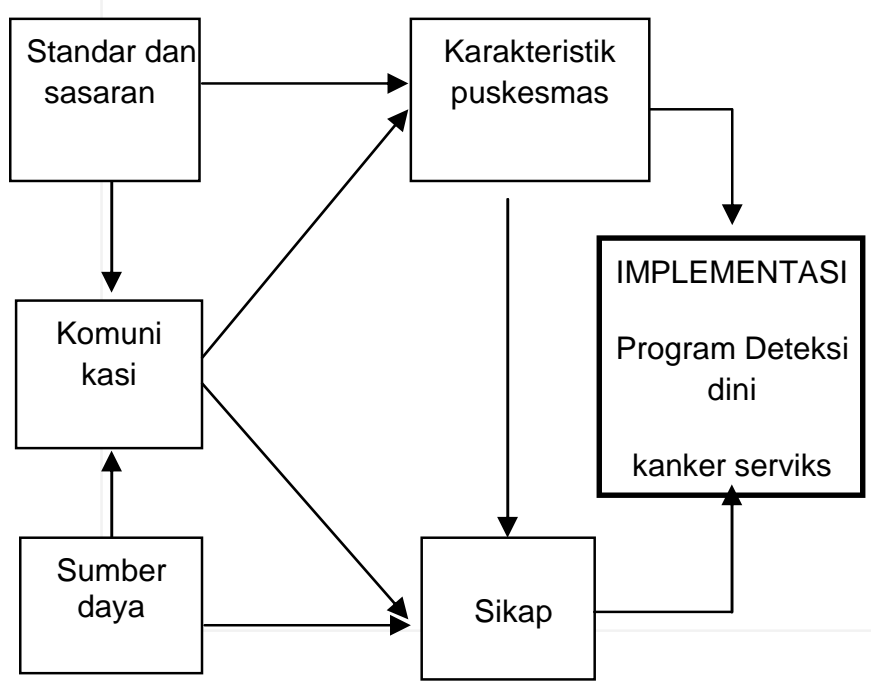

Gambar 4.2 Teori Faktor-faktor implementasi menurut van Meter dan Van Horn

Berdasarkan hal tersebut pengaruh antarakomunikasi, sikap, karakteristik badan pelaksana, sumber daya serta standar dan sasaran terhadap implementasi program IVAoleh Puskesmas di wilayah kota Surabaya dapat digambarkan sebagai berikut :

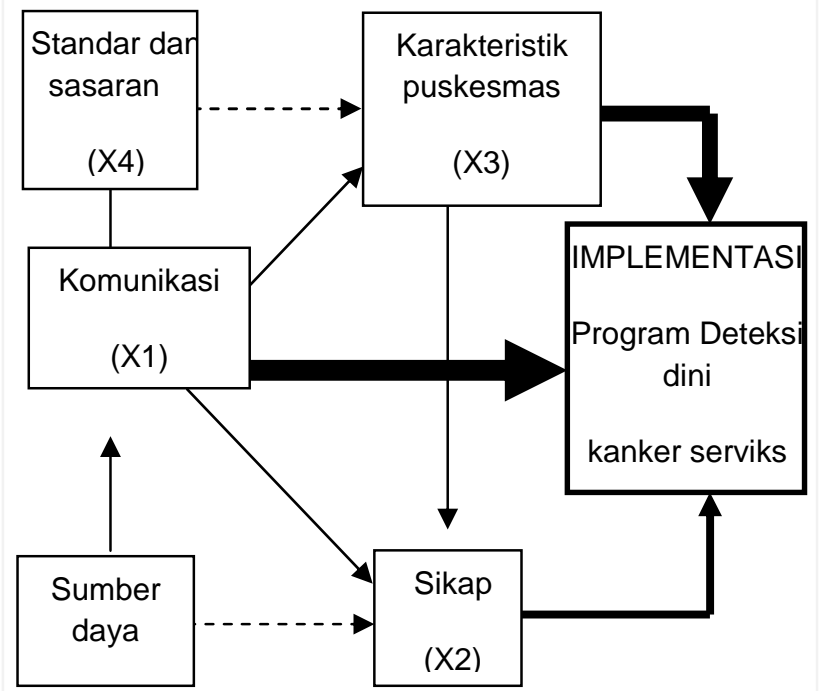

Gambar 4.3 Diagram jalur faktor-yang mempengaruhi implementasi programin IV A di Püskesinas wilayah kota Surabaya.
Hasil penelitian ini mengkonfirmasi teori tentang teori implementasi menurut Van Meter dan Van Hornyang menggambarkan implementasi suatu kebijakan dipengaruhi langsung oleh sikap dan karakterristik badan pelaksana, hal tersebut sesuai dergan yang didapatkan pada implementasi program IVA di Surabaya. Sedangkan komunikasi yang digambarkan secara teori sebagai faktor tidak langsung ternyata memiliki pengaruh langsung yang signifikan terhadap implementasi, bahkan memiliki pengaruh paling besar terhadap implementasi yaitu 50,3\%. Hal tersebut karena komunikasi merupakan faktor penting yang dapat mempengaruhi kecenderungan karakter puskesmas dan sikap pelaksana dimana kedua faktor tersebut merupakan faktor penting dalam implementasi. Van Meter dan Van Horn menjelaskan bahwa kebijakan dapat dilaksanakan dengan baik jika terjadi komunikasi efektif antara pelaksana program dengan target group.

Komunikasi memegang peranan terbesar dalam implementasi program IVA di Surabaya. Di Surabaya, pertemuan antara pemegang program di DKK dengan kepala puskesmas dan penanggung jawab program tingkat puskesmas rutin dilaksanakan, namun pertemuan tidak spesifik membahas proram/kegiatan tertentu, melainkan tentang penyampaian monitoring semua program yang ada dipuskesmas secara garis besar. Program yang dibicarakan cukup banyak sehingga pembahasan untuk masing program termasuk program IVA tidak dapat dilakukan secara jelas dan optimal. Hasil penelitian pada jawaban responden, program IVA dipersepsikan bukan sebagai program yang harus dilakukan oleh seluruh puskesmas namun target SPM 25orang/bulan hanya ditekankan pada daerah yang awarness/ beresiko tinggi kanker serviks yaitu puskesmas yang di wilayah kerjanya terdapat daerah lokalisasi. Hal tersebut menggambarkan adanya perbedaan persepsi antara DKK 
dan puskesmas tentang wajib tidaknya program IVA, target yang ditetapkan dan sasaran target program IVA.

Menurut George Edward, informasi yang tidak diberikan atau diterima secara jelas dan konsisten akan menimbulkan perbedaan persepsi/pemahaman antara regulator dengan implementor tentang tujuan kebijakan. Perbedaan persepsi ini berdampak pada tidak efektifnya kinerja dalam implementasi terlebih pada program yang relatif baru ditetapkan, oleh karena itu komunikasi merupakan langkah awal dari keberhasilan suatu kebijakan.

Pembentukan sikap dan peningkatan dukungan puskesmas dimana merupakan faktor penting yang berpengaruh langsung terhadap implementasi dan keduanya juga dipengaruhi oleh komunikasi. Dari sisi individu pelaksana/ penanggungjawab program komunikasi berkaitan erat dengan pembentukkan persepsi yang dapat mempengaruhi pemahaman dan kecenderungan sikap terhadap hal tersebut, pemahaman yang kabur akan membuat pelaksana bersikap menolak mengenai program dan ini dapat membuat implementasi tidak akan berjalan sesuai yang diharapkan. Dari sisi badan pelaksana (puskesmas), komunikasi yang efektif ke seluruh pelaksana dapat meningkatkan antusiasme anggota dalam organisasi.

Menurut Taibi Kahler (Kahler Comunication), komunikasi bukan hanya sekedar aktifitas penyampaian informasi, tetapi upaya untuk mempengaruhi serta menguatkan persepsi dan sikap sasaran sesuai dengan yang dikehendaki. Komunikasi merupakan faktor penting terutama pada kejelasan standar dan tujuan, akurasi komunikasi para pelaksana dan konsistensi (kesamaan) yang dikomunikasikan dan bermacammacam sumber informasi. Pemahaman oleh individu yang bertanggung jawab dalam implementasi kebijakan sangat penting, pemahaman yang kabur akan membuat pelaksana bersikap menolak mengenai program dan ini dapat membuat implementasi tidak akan berjalan sesuai yang diharapkan.

Sumberdaya dan pemahaman tentang standar dana sasaran kebijakan juga berpengaruh terhadap implementasi. Sikap dan dukungan puskesmas terhadap program IVA kurang maksimal karena tidak adanya ketetapan jelas serta kompensasi penyediaan sumberdaya yang memadai. Tidak tersedianya alokasi dana khusus untuk program IVA serta tidak adanya kompensasi tindak lanjut baik berupa reward bagi puskesmas yang berhasil maupun panishment bagi yang tidak melaksanakan menimbulkan persepsi bahwa target program ini tidak wajib dicapai, terlebih sasaran target program sangat luas sehingga perlu kerjasama dengan berbagai pihak dan hal tersebut membutuhkan sumberdaya yang optimal.

Standar dan sasaran yang kabur/tidak jelas apakah suatu program sifatnya diwajibkan atau tidak, serta standar target apa yang harus dicapai akan menyebabkan adanya hambatan dalam komunikasi. Begitupula sumberdaya, penyediaan sumberdaya tidak hanya pada sarana prasarana dan SDM saja, melainkan segala yang dibutuhkan dalam implementasi program termasuk dana. Tidak tersedianya sumberdaya yang optimal serta standar dan sasaran yang kabur/tidak jelas tentang suatu program serta menimbulkan distorsi/hambatan baik dalam proses komunikasi maupun implementasi suatu kebijakan.

\section{SIMPULAN}

1. Komunikasi tentang implementasi program IVA sebagian besar $(51,9 \%)$ kurang baik khususnya dalam hal kejelasan informasi, sikap penanggungjawab 55,8\% positif/mendukung program IVA, karakteristik puskesmas sebagian besar $53,8 \%$ kurang memberikan dukungan dalam struktur organisasi, pemahaman 
tentang standar dan sasaran program $51,9 \%$ kurang khususnya tentang ketetapan status program dan target yang harus dicapai.

2. Implementasi program IVA oleh puskesmas di wilayah Kota Surabaya $57,7 \%$ kurang dalam melakukan pemetaan sasaran, penyuluhan dan cakupan pemeriksaan.

3. Komunikasi, karakteristik dukungan puskesmas dan sikap penanggungjawab program masingmasing berpengaruh secara langsung terhadap implementasi program IVA.

4. Sumberdaya dan pemahaman tentang standar sasaran berpengaruh secara tidak langsung terhadap implementasi program IVA.

5. Komunikasi, sikap, karakteritik dukungan puskesmas, sumberdaya dan pemahaman tentang standar sasaran secara bersama-sama berpengaruh terhadap implementasi program IVA dengan prediksi sebesar $80,7 \%$ dimana variabel yang paling berpengaruh adalah komunikasi.

\section{DAFTAR PUSTAKA}

1. World Health Organization. Comprehensive Cervical Cancer Control. A Guide to Essential Practice. Geneva : WHO, 2007.

2. Kepmenkes RI Nomor 796/Menkes/SK/VII/2010. Pedoman Teknis Pengendalian Kanker Payudara dan Kanker Leher Rahim. 2010

3. Canavan TP, Doshy NR. Cervical Cancer. Situs American Family Physician. www.aafp.org. 2002. Diakses tanggal 2 Januari 2013

4. Holowaty P et al. Natural History of dysplasia of the uterine cervix. Journal of the National Cancer Institute. 2005

5. Benedet JL, Ngan HYS, Hacker NF. Staging Classifications and clinical practice guidelines of gyneecologic cancers. Int J Gynecol Cancer. 2000

6. Dwiyanto,Indiahono. Kebijakan Publik Berbasis Dynamic Policy
Analisys;Gava Media:

Yogyakarta,2009.

7. Subarsono. Analisis Kebijakan Publik Teori dan Aplikasi. Penerbit : Pustaka Pelajar, Yogyakarta. 2012.

8. Winarno, Budi. Kebijakan Publik, Teori dan Proses. Medika Press: Yogyakarta, 2008

9. Agustinus, Leo. Dasar-Dasar Kebijakan Publik. Alfabeta, Bandung, 2008

10. Solahuddin Kusumanegara, Model dan Aktor dalam Proses Kebijakan Publik, Penerbit Gava Media, Yogyakarta, 2010.

11. Ekowati Mas Roro Lilik, Perencanaan, Implementasi dan Evaluasi Kebijakan atau Program. Pustaka cakra. Surakarta. 2009

12. Juanim. Analisis Jalur dalam Penelitian. Fakultas Ekonomi UNPAS. Bandung.2004

13. Ghozali Imam. Structural Equation Modeling dengan Alternatif Partial Least Square. UNDIP. Semarang.2011.

14. Nurjazuli. Paradigma Baru dalam Analisa data Penelitian SEM dengan VPLS. UNDIP. Semarang. 2012.

15. Gibson, James L. John M. Ivancevich J.H. Donelly Jr.Organization. Organisasi Perilaku, Struktur dan Proses. Jakarta: Erlangga

16. Surasmi, Arsining.dkk (2005). Perawatan Bayi Resiko Tinggi. Jakarta: ECG

17. Tiran, Denise (2005). Kamus Saku Bidan edisi 10. Jakarta: ECG

18. Varney, H.dkk (2007). Buku Ajar Asuhan Kebidanan edisi 4. Jakarta: EGC

19. Winkjasastro, H (2005). Ilmu kandungan. Jakarta :Yayasan Bina Pustaka- Sarwono Prawiroharjo 